\title{
Rickettsia prowazekii
}

National Cancer Institute

\section{Source}

National Cancer Institute. Rickettsia prowazekii. NCI Thesaurus. Code C86723.

A species of aerobic, Gram negative, rod and cocci shaped bacteria assigned to the phylum Proteobacteria. This species is oblig ately intracellular, motile and transmitted to humans by the human body louse, Pediculus humanus corporis. R. prowazekii is a pathogen that causes epidemic typhus and Brill Zinsser disease. 